\title{
Penetrating orbitocranial injury with a snooker cue
}

A young man playing snooker was awaiting his turn, holding the cue with the butt resting on the floor, when he was playfully punched in the stomach by an opposing team member. He doubled up and the tip of the cue penetrated his upper eyelid. He withdrew the cue and attended the casualty department unaided. Apart from hyphaema the eye was unscathed. Four hours later he became unconscious and computed tomography showed a massive intracranial injury (figure). A large right intracerebral haematoma extended from the ganglionic region to the frontal lobe inferiorly and there was extracranial soft tissue swelling over the right frontal bone.

Penetrating orbital wounds frequently extend intracranially..$^{1-8}$ The diagnosis is missed because the entry wound is small, ${ }^{3}$ vascular and infective complications are often delayed, ${ }^{1247}$ and conventional radiography is unreliable. ${ }^{2}$ A CT scan is essential. ${ }^{9}$

Before neurosurgical intervention cerebral angiography is advisable to exclude vascular damage. ${ }^{10}$ Postoperatively this patient recovered with a residual hemiparesis. Clearly, an intracranial component must be suspected in any penetrating orbital wound. $-G$ R KIRKBY, Birmingham and Midland Eye Hospital, Birmingham B3 2NS.

I thank Mr D Price and Mr B Harcourt for advice and criticism, Dr M Nelson for reporting on the CT scan, and Miss A Gelder for typing the manuscript.

I Duffy GP, Bhandari YS. Intracranial complications following transorbital penetrating injuries. Brf Surg 1969;56:685-8.

Bard LA, Jarrett WH. Intracranial complications of penetrating orbital injuries. Arch Ophthalmo 1964;71:332-43.

3 Guthkelch AN. Apparently trivial wounds of the eyelids with intracranial damage. $\mathrm{Br} \mathrm{Med} \mathcal{f}$ 1960;ii:842-4.

4 Hamilton JG. Orbital injury and carotico-cavernous fistulae. 7 Neurol Neurosurg Psychiatry 1966;29:476.

5 Duke-Elder S. Wounds of the adnexa: penetrating wounds of the orbit. In: Duke-Elder S, ed. System of ophthalmology. Vol 14. Pt I. London: Kimpton, 1972:437-48.

6 Dabezies OH, Naugle TC Sr, Naugle TC Jr. Penetrating orbital injury caused by an "Afro comb." Ann Ophthalmol 1982;14:780-2.

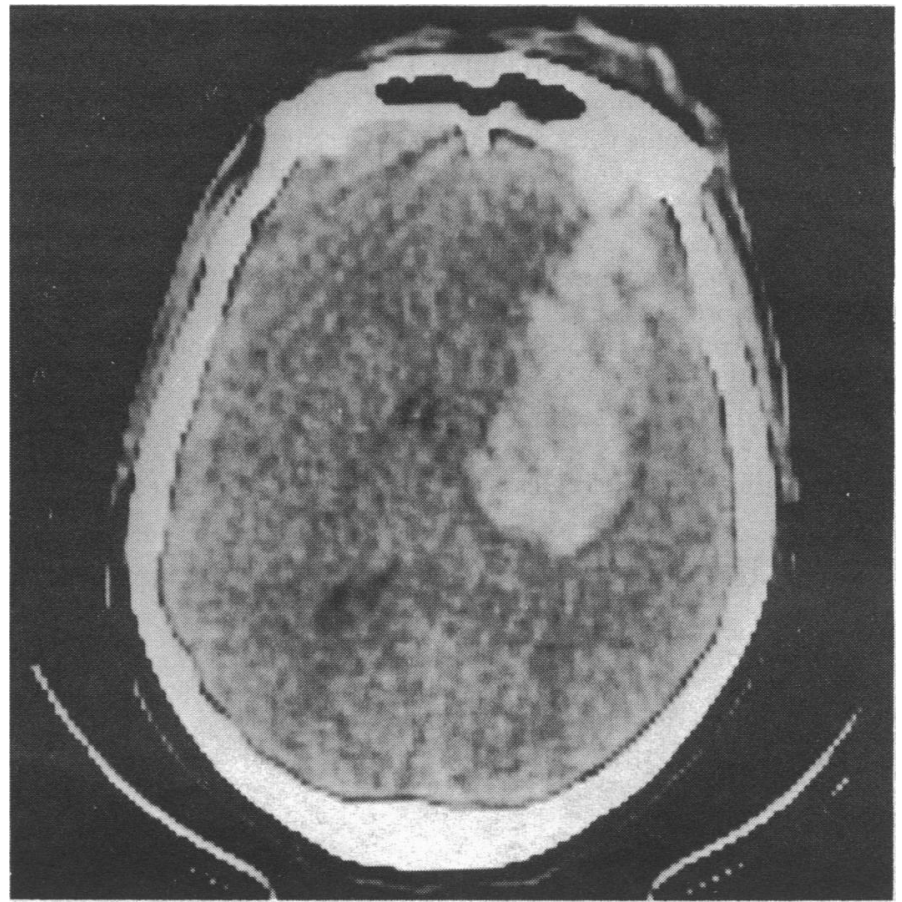

7 Amano K, Shuji K. Cerebellar abscess due to penetrating orbital wound. 7 Comput Assist Tomogr 1982;6:1163-6.

8 Carothers A. Orbitofacial wounds and cerebral artery injuries caused by umbrella tips. $\mathcal{F A M A}$ 1978;239:1151-2.

9 Lunsford LD, Woodford J, Drayer BP. Cranial compured tomographic demonstration of intracranial penetration by an orbital foreign body. Neurosurgery 1977;1:57-9.

10 De Villiers JC. Stab wounds of brain and skull, In: Vinken OJ, Bruyn JW, eds. Handbook of clinical neurology. Vol 1. Amsterdam: North-Holland Publishing Co, 1975:477-503.

\section{Outbreak of Weil's disease in a food fad commune in India}

Weil's disease is rare in India. Though the society is predominantly vegetarian, there is a small community that is unique in its habit of catching, cooking, and eating rats, mice, and snakes. Found in eastern India, this poor and gypsy like wandering community is known as mussher, a name derived from "Muss," which means "mouse" in the local language. Such communes bear the social stigma of being untouchable, and they make their temporary settlements on the outskirts of villages.

We report an outbreak of seven cases of Weil's disease in a commune of 40 people after a feast of rat meat.

\section{Case report}

In late September (after the rainy season in India) a 17 year old woman was admitted after complaining for seven days of high colour urine and pain over her right hypochondrium. She had been feverish for three days with a fluctuating temperature of up to $42 \cdot 2^{\circ} \mathrm{C}$. She had appreciable anorexia and nausea and had vomited occasionally. Ten days earlier she had eaten rat meat (Rattus rattus) that she had been offered by a wandering commune that had settled beside her house.

On clinical examination she was found to have a high temperature, severe icterus, suffused conjuntivas, hepatosplenomegaly, and a stiff neck. The results of investigations showed: white cell count $30.4 \times 10^{9} / 1$ with $90 \%$ polymorphs, bilirubin $135 \mu \mathrm{mol} / \mathrm{l}(7.9 \mathrm{mg} / 100 \mathrm{ml})$, alanine aminotransferase $400 \mathrm{IU} / \mathrm{l}$, alkaline phosphatase $21.0 \mathrm{KAU} / \mathrm{l}$, creatinine $106 \mu \mathrm{mol} / 1(1.2 \mathrm{mg} / 100 \mathrm{ml})$, sodium $140 \mathrm{mmol}(\mathrm{mEq}) / 1$, and potassium $4.2 \mathrm{mmol}(\mathrm{mEq}) / 1$. The results of routine urine examination showed albuminuria and the presence of bile salts and bile pigments. Cerebrospinal fluid contained protein $0.5 \mathrm{~g} / \mathrm{l}$, glucose $2.4 \mathrm{mmol} / \mathrm{l}(44 \mathrm{mg} / 100 \mathrm{ml})$ and white cells $25 \times 10^{6} / 1$ with $80 \%$ lymphocytes. No malaria parasites or Leishman-Donovan bodies were found in thick or thin blood smears. Urine culture showed no growth. Results of Venereal Disease Research Laboratory and
Wassermann reaction blood tests were negative. Leptospira was present in urine cultured on a special medium containing fluorouracil.

She responded well to treatment with penicillin and general care and was discharged after three weeks completely recovered.

\section{Epidemiological study}

Epidemiological setting-After the index patient had presented we located the commune and made inquiries. The outbreak had occurred in a small village near Patna on the bank of the Ganges. After harvest the beds of the paddy fields were dry and heavily infested with rats.

Epidemiological survey - The commune comprised 40 people, all of whom were descendants of a common grandparent. None had suffered from jaundice in the past. Seven members aged 4 to 36 were suffering from an acute febrile illness associated with jaundice and conjunctival suffusion (table). Of these seven patients, three children did not participate in the catching or cooking of the rats. The patients were erroneously presumed to be suffering from viral hepatitis; all

Clinical features of cases of Weil's disease in commune

\begin{tabular}{|c|c|c|c|c|c|c|c|c|}
\hline \multirow[b]{2}{*}{$\begin{array}{c}\text { Case } \\
\text { No }\end{array}$} & \multirow[b]{2}{*}{$\begin{array}{c}\text { Age } \\
\text { (years) }\end{array}$} & \multirow[b]{2}{*}{ Sex } & \multirow[b]{2}{*}{$\begin{array}{l}\text { Incubation } \\
\text { period } \\
\text { (days) }\end{array}$} & \multicolumn{4}{|c|}{ Main clinical features } & \multirow{2}{*}{$\begin{array}{l}\text { Leptospira } \\
\text { in urine } \\
\text { shown by } \\
\text { culture }\end{array}$} \\
\hline & & & & $\begin{array}{l}\text { Tempera- } \\
\text { ture } \\
\text { range }\left({ }^{\circ} \mathrm{C}\right)\end{array}$ & $\begin{array}{c}\text { Bilirubin } \\
\text { concentration } \\
(\mu \mathrm{mol} / \mathrm{l})\end{array}$ & $\begin{array}{l}\text { Albumin } \\
\text { present } \\
\text { in urine }\end{array}$ & $\begin{array}{l}\text { Stiffness } \\
\text { in neck }\end{array}$ & \\
\hline 1 & 16 & $M$ & 10 & $38 \cdot 9-40 \cdot 0$ & $68 \cdot 4$ & +++ & Yes & Yes \\
\hline 2 & 36 & $M$ & 10 & $38 \cdot 3-40 \cdot 0$ & $119 \cdot 7$ & + & N & No \\
\hline 3 & 12 & $\mathrm{~F}$ & 12 & $38 \cdot 3-39 \cdot 4$ & $66 \cdot 7$ & ++ & No & Yes \\
\hline 4 & 4 & $M$ & 12 & $36 \cdot 7-38 \cdot 9$ & $73 \cdot 5$ & Trace & Yes & No \\
\hline 5 & 25 & $\mathrm{~F}$ & 16 & $37 \cdot 2-39 \cdot 4$ & $59 \cdot 9$ & ++ & No & Yes \\
\hline 6 & 29 & $M$ & 17 & $37 \cdot 2-40 \cdot 6$ & $49 \cdot 6$ & + & Yes & No \\
\hline 7 & 9 & $M$ & 18 & $37 \cdot 8-40 \cdot 0$ & $32 \cdot 5$ & +++ & No & Yes \\
\hline
\end{tabular}

Conversion: SI to traditional units-Bilirubin: $1 \mu \mathrm{mol} / 1 \approx 0.06 \mathrm{mg} / 100 \mathrm{ml}$ 
were negative for hepatitis B surface antigen. Three showed signs of meningeal irritation, and leptospira was present in the urine of four. On serological testing all patients yielded a positive result of a microscopic agglutination test at a titre of $1 / 100$; none of the healthy subjects showed a titre greater than $1 / 10$. All patients recovered after treatment with penicillin.

Animal studies-Ten rats were caught from the paddy fields and from the house of the index patient. Leptospira was isolated from the urine culture of eight rats caught from the field but not from that of any of those caught in the house.

\section{Discussion}

Weil's disease is transmitted by a wide range of domestic animals such as rats, cattle, swine, goats, foxes, raccoons, cats, deer, opossums, and dogs, even immunised ones. ${ }^{1}$ Of these animals, rats have been recognised as the most important hosts for leptospira. ${ }^{2}$ Infection in man may occur either through direct contact with the urine or tissues of infected animals or through contaminated water, food, soil, or vegetation. The sites of entry in man are through abraded skin, particularly on the feet, and exposed conjunctival, nasal, and oral mucous membranes. ${ }^{3}$ Infection through the intestinal mucosas can occur when food contaminated with leptospira is ingested in quantity.

Outbreaks of leptospirosis have been reported after outdoor recreational exposure, after contact with pets, especially dogs, ${ }^{1}$ and after occupational exposure in miners, veterinarians, shepherds, and farmers. ${ }^{5}$ The outbreak reported here seems to be unique in that the disease occurred after eating the infected animal itself. The commune had just migrated to that area and had had a very good catch of rats. The feast on rat meat was followed 10-18 days later by the cases of Weil's disease.

Wandering communes such as these are extremely poor and rely mainly on rat meat as a source of non-vegetarian food. They do not have proper cooking facilities, usually building a makeshift bonfire in the fields. In addition, the habit of eating rat meat is socially condemned by the villagers, resulting in very hasty cooking. Some leptospires present in deeper layers of the infected rat meat probably therefore survived this inadequate and short lived cooking. This view is supported by the observations of Pardisi et al, who recorded the temperature at the centre of Florentine steaks $(3-4 \mathrm{~cm}$ thick) cooked on an electric hot plate. They found that a cooking time of seven to eight minutes produced a temperature of only $32-35^{\circ} \mathrm{C}$ at the centre of the steak. ${ }^{6}$ Even though leptospira is very susceptible to heat, a temperature of $50^{\circ} \mathrm{C}$ maintained for 10 minutes or $60^{\circ} \mathrm{C}$ for 10 seconds is required to kill it completely. ${ }^{7}$ In this outbreak no rat meat was cooked for longer than five to six minutes.

Several points suggest that the food was the source of the outbreak. Firstly, all the cases occurred within the normal incubation period for leptospirosis (two to 26 days) ${ }^{3}$ after the day of the feast. Before this none of the members of the commune had suffered from jaundice, and during a follow up period of six months no new cases occurred. Secondly, children aged less than 4 , who were not fed the rat meat, did not suffer, though they used to play and walk barefoot in the rat infested fields. Thirdly, the index patient, who did not belong to the commune, suffered from Weil's disease 10 days after eating the rat meat. She did not participate at all in catching, handling, or cooking the rats. Her only point of contact with the commune was the feast. Fourthly, the disease did not occur in any other member of the family of the index patient or in the villagers. Finally, leptospira was cultured only from urine of the rats caught from the field and not from urine of rats trapped in the house.

Though the association between rats and leptospira has been known since $1915,{ }^{8}$ this unique mode of spread among food faddists has until now not been recognised.

1 Feigin RD, Lobes LA, Pickering L. Human leptospirosis. Ann Intern Med 1973;79:777-85. 2 Heath CW Jr, Alexander AD, Galton MM. Leptospirosis in the United States. N Engl f Med 1965;273:857-64.

3 Sanford JP. Leptospirosis. In: Petersdorf RG, Adams RD, Braunwald U, Isselbacher KJ, Martin JB, Wilson JD eds. Harrison's principles of internal medicine. New York: McGraw Hill, 1983: 1048-51.

4 Stiprija V. Leptospirosis. In: Weatherall DJ, Ledingham JGG, Warrell DA, eds. Oxford textbook of medicine. Oxford: Oxford University Press. 1984:297.

5 Steigman AJ. Leptospirosis. In: Nelson WE, Vaughan VC, McKay RJ, Behrman RE, eds. Textbook of paediatrics. 1lth ed. Philadelphia: W B Saunders and Co, 1979:849-50.

6 Pardisi F, Bartoloni A, Aquilini D. Is fast food toxo-food? N Engl f Med 1985;313:1092.

7 Ananthanarayan R, Jayarampaniker CK. Leptospira. In: Ananthanarayan R, Jayarampaniker CK, eds. Textbook of microbiology. Madras: Orient Longman, 1981:358.

8 Inada R, Ido Y, Hoki R, et al. Aetiology, mode of infection and specific therapy of Weil's disease. $\mathcal{F}$ Exp Med 1916;23:377-402.

(Accepted 5 September 1986)

Department of Medicine, Patna Medical College and Hospital, Patna, Bihar, India-800004

PRADIP K AGRAWAL, MB, BS, postgraduate student

D K SRIVASTAVA, $M B, M D$, professor of medicine

Correspondence to: Professor Srivastava.
From exhaustion, exposure, and hunger to extreme voraciousness: bulimia

As the clinical condition known as bulimia has become a fashionable diagnosis over the past five years we thought it would be of interest to describe the origins of this word and trace the evolution of its meanings from ancient Greek times to the present.

Bulimia is derived from the Greek words $\beta o \hat{\zeta} \zeta$ (ox) and $\lambda \iota \mu$ ó $\zeta$ (hunger), indicating a great hunger or, literally, so hungry that one could eat either an ox or as much as an ox. In Xenphon's Anabasis, written about 370 BC

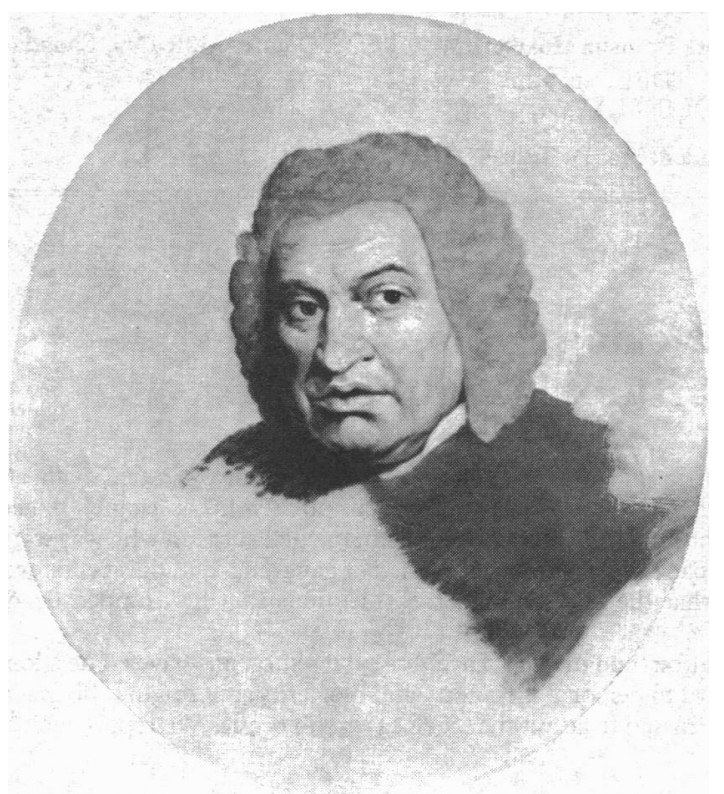

Samuel Johnson. (National Portrait Gallery, London.)

bulimia was used to describe a state of profound hunger, exhaustion, and exposure suffered by a small army of Greek soldiers while they were traversing snow covered mountains in what is now eastern Turkey:

The whole of the next day's march from here was through the snow, and a number of soldiers suffered from bulimia. Xenophon, who, as he commanded the rearguard, came upon men who had collapsed, did not know what the disease was. However someone who had had experience of it told him that it was a clear case of bulimia, and that if they had something to eat, they would be able to stand up. So he went through the baggage train and distributed to the sufferers any edibles that he could find there, and also sent round those who were able to run with more supplies to them. As soon as they had something to eat they stood up and went on marching. ${ }^{2}$

This passage implies that once these soldiers were fed they improved and were fit to carry on. There is no suggestion of any mental disorder: it seems to have been a naturally occurring hunger. There is also a connotation of cold exposure. In fact, the translator's note defines the term as follows: "Bulimia - the Greek word for what is apparently a state of exhaustion caused by cold and lack of food."3

The word's first documented use in English was as a medical term to signify a morbid hunger, a so called "canine hunger" occurring chiefly in idiots and maniacs as documented in a tract from Trevisa in 1398: "Bolismus is inmoderate and vnmesurable as it were an houndes appetyte." By 1751 the association with mental disorders was well established, as described by Brooke: "A Bulimus is a Disease wherein the patient is affected with an insatiable and perpetual Desire of Eating."'

Thereafter the term was used more loosely to describe an unusual voraciousness, as in the following two quotations.

The bulimious Doctor Johnson could not have transacted his feeding so porcinely and perspiringly.

He [Dr Johnson] was totally absorbed in the business of the moment; his looks seemed rivetted to his plate; nor would he unless in very high company, say one word, or even pay the least attention to what was said by others, till he had satisfied his appetite, which was so fierce, and indulged with such intenseness, that while in the act of eating, the veins of his forehead swelled and generally a strong perspiration was visible. ${ }^{4}$

Thus, probably entirely due to Dr Johnson's prodigal gluttony for food, bulimia has come to mean extreme voraciousness. 